\title{
Effect of Phosphate Dissolving Bacteria on Physiological Behavior of Some Sesame Cultivars under Saline Conditions at Sahle Eltina- North Sinai
}

\author{
Amal M. Omer ${ }^{1}$ and Ahmed S. Abd-Elnaby ${ }^{2}$
}

\begin{abstract}
Four highly efficient halotolerant phosphates solubilizing bacteria (PSB) were investigated for their activities under saline conditions. Increasing salinity over 3\% NaCL concentration had a negative effect on both phosphatase activity and $\mathrm{pH}$ reduction resulting a net reduction in their phosphate solubilization activity. The four strains could secrete multiple organic acids under saline condition. Both Pseudomonas geniculate and Alcaligenes faecalis had achieved the maximum phosphate solubilization at $3 \% \mathrm{NaCL}$.

Green house experiment was conducted for evaluation of four sesame cultivars (Sohag, Giza 32, Shandaweel and Zail Elgamal) and two phosphates solubilizing bacteria (Alcaligenes faecalis and Pseudomonas geniculate) and mixture of them under saline conditions. The results revealed that Giza 32 was the most resistant cultivar to salinity while Zail Elgamal cultivar was the lowest one, at the same time, mixture of two PSB was more efficient than single bacterial inoculation.

Two growing seasons were conducted at Sahle ElTina, North Sinai to study the potential of PSB mixture and KCL foliar application on the growth and productivity of sesame cultivar Giza 32. The highest significant increase in sesame yield, oil content and chemical constituents of sesame seeds were recorded by the interaction of biofertilizer and foliar application in both seasons. Gas liquid chromatography analysis indicated that the unsaturated fatty acid constituents in sesame oil were oleic, linoleic and linolenic acid while the predominant saturated acids were palmitic and stearic acids. Dual inoculation of biofertilizer and foliar applications recorded the the highest bacterial counts and phosphatase enzyme activity in the rhizosphere regions.
\end{abstract}

Key words : Sesame ; Pseudomonas sp. ; Alcaligenes sp. ;salinity.

\section{INTRODUCTION}

Phosphorus (P) is often the most limiting macronutrient for plant growth required in relatively large amounts by plants. One of the main roles of $\mathrm{P}$ in living organisms is in the transfer of energy. It plays a significant role in several physiological and biochemical plant activities like photosynthesis, transformation of sugar to starch, transporting of the genetic traits and supplying energy required for metabolic processes (Lal, 2002). Although phosphorus is abundant inboth organic and inorganic forms in the soil, it is one of the major plant growth-limiting nutrient that it is mostly present in an insoluble form that a large proportion of applied $\mathrm{P}$ in the soil becomes static (Rahmatullahet al., 1994). The availability of this nutrient for plants is limited by different chemical reactions especially in arid and semiarid soils as well as alkaline sandy soil which causes the conversion of phosphorus content to unavailable form, mainly as tricalcium phosphate. The efficiency of $\mathrm{P}$ fertilizer throughout the world is around $10-25 \%$ (Isherword, 1998) and the concentration of bio available $\mathrm{P}$ in soil is very low reaching the level of $1.0 \mathrm{mg} \mathrm{kg}^{-1}$ soil (Goldstein,1994).

Salinization of soil is a serious problem which increased gradually in many parts of the world, particularly in arid and semiarid areas, nearly $40 \%$ of world's surface has salinity problems (Jadhavet al., 2010). Expanding problems of soil salinity and water logging have become serious issues of concern that they affect productivity and sustainability of agriculture. The impact of soil salinity on the concentration of phosphorus in plants depends mainly on plant species, the type and level of salinity and concentration of phospohorus that is already present in the soil (Grattan \& Grieve, 1999). In most cases, excess of salts in soil solution leads to a reduction in phosphorus concentration in the tissues of plants (Sonneveldand de Kreij, 1999, Kaya et al. 2001). The reduction of phosphorus availability in saline soils is the result of the activity of ions antagonists, which can reduce the activity of phosphate and phosphate transporters of both high and low affinity, which are necessary for the uptake of phosphorus (Kochian, 2000). Reduction of phosphorus uptake may be a result of the high effect of sorption processes which control the concentration of phosphorus in the soil and low solubility of Ca-P minerals (Marschner, 1995).

The growth of phosphate-solubilizing bacteria (PSB) are playing a key role in phosphorus solubilization in the soil(Abd-Alla , 1994) that they can transform the insoluble phosphorus to soluble forms $\mathrm{HPO}^{-2}$ and $\mathrm{H}_{2} \mathrm{PO}^{-4}$ by acidification, chelation, exchange reactions and polymeric substances formation(Delvasto et al. 2006).Many PSB have been isolated including, for example, those in Bacillus, Pseudomonas, Erwinia,

\footnotetext{
${ }^{1}$ Soil Fertility and Microbiology Department and

${ }^{2}$ Genetic Resources Dept., plant Adaptation Unit,

Desert Research Center, Cairo, Egypt

Received September 14,2017, Accepted Octobr25, 2017
} 
Agrobacterium,

Enterobacter,

Bradyrhizobium,

Serratia Micrococcus,

Salmonella,

Flavobacterium, Azotobacter, Alcaligenes,

Chromobacterium, Arthrobacter, Streptomyces, Thiobacillus and Escherichia(Zhao and Lin, 2001).Therefore, the use of phosphate solubilizing microbes in agricultural practice would not only overcome the high cost of manufacturing phosphatic fertilizers but also could mobilize insoluble phosphorus in the fertilizers and soils to which they are applied. The salinity stress causes less effect on halotolerant bacteria since they have adapted during evolution to tolerate and optimally grow in hyper saline environments(Nautiyal et al.,2000).So, application of salt-tolerant or halophilic PSB will facilitate the development of saline-alkali soilbased agriculture.

Foliar application of potassium can also be used for alleviating stress on plants. Potassium is a key essential plant nutrient although it is not a constituent of any plant part. It acts as catalyst for many of the enzymatic processes which are necessary for plant growth. It also regulates the opening and closing of stomata which affect carbon dioxide uptake for photosynthesis (Somida, 2002). Also, potassium has an important role in translocation of metabolites from source to sink (Kramer, 1980).Adequate potassium levels in the plant help it to withstand water stress during periods of drought. Potassium regulates the osmotic turgor of the cells and the water balance. Crops grown with adequate potassium availability use less water per unit weight of plant biomass and are therefore better able to survive periods of drought( El-Latifet al. 2011).

Sesame (Sesamum indicum L.) is a crop grown in many parts of the world for production of high quality oil and its insecticidal and medicinal properties as well as for its cosmetic and ornamental values. Total area under sesame production in Egypt has increased from 11,264 ha in 1961 to 36,907 ha in 2010 and the productivity increased from $1,145.7 \mathrm{~kg} / \mathrm{ha}$ in 2005 to $1,250.3 \mathrm{~kg} / \mathrm{ha}$ in 2010 (Faostat, 2012). It is grown in many governorates and ranks first among the cultivated oil cropsin Ismailia Governorate (El-Bramawy, 2006). The seed of sesame contains about 50 to $51 \%$ oil, 17 to $19 \%$ protein and 16 to $18 \%$ carbohydrate and that the oil is edible, odourless and semi-drying, containing oleic, stearic and palmitic acids. Sesame oil serves as antioxidant in the manufacture of margarine and salad creams, and as a fixative in the industries for making of perfumes and cosmetics (Yermanoset al. 1972).

The present investigation was designed for evaluation of four sesame cultivars under salinity stress and potential of different PSB as P solubilization at salt stress and their effect on the yield ,chemical composition and microbial activity of sesame cultivars.

\section{MATERIALS AND METHODS}

The present investigation consisted of two experiments at nursery and field experiments as follows:-

Evaluation of phosphates solubilizing bacteria (PSB) strains under saline condition : Four highly efficient halotolerant phosphates solubilizing bacteria previously isolated from saline soils and identified using partial 16S rRNA gene sequence technique as (B. subtilis ATCC 6633, Pseudomonas geniculate strain ATCC 19374, Azotobacter chroococcum and Alcaligenes faecalis strain NBRC 13111) were investigated for their activities as PSB under saline conditions ranged from 0 to $10 \%$ NaCL concentrations. The phosphate solubilizing activities of bacterial strains included the following:

-Change in the $\mathrm{pH}$ of Pikovskaya broth media after three days of bacterial inoculation

-Quantitative amount of soluble phosphate in liquid cultures after three days of bacterial inoculation using molybdenum blue method of Watenabe and Olsen (1965).

-Phosphatase activity after three days of bacterial inoculation was estimated by Tabatabai and Brimner method (1969). One enzyme unit of phosphatase was defined as amount of enzyme that hydrolyzed $1 \mathrm{mM}$ of p-nitrophenol hour ${ }^{-1}$.

-Organic acid analysis of Pikovskaya broth media at different concentrations of NaCL ( The concentrations at which the selected strains exhibited the maximum solubilization activity ) after three days of bacterial inoculation using HPLC equipped with a UV detector as described by Aktaset al.,( 2005).

\section{Pot experiment}

Pot experiment was conducted in the green house of microbiological unit of Desert Research Center to evaluate the four cultivars of sesame and two phosphates solubilizing bacteria under salt conditions. Sesame cultivars to be evaluated were : Sohag, Giza 32, Shandaweel and ZE (Zail Elgamal) while PSB were : Alcaligenes faecalis and Pseudomonas geniculate and mixture of them. The Experimental design was a randomized complete block design with three replications. The main block was devoted to sesame cultivars and sub block to bio-fertilizers. Seeds of different sesame cultivars were planted into10 $\mathrm{kg}$ pot containing soil of Sahle El-Tina. For bacterial treatments, seeds were coated with bacterial inoculum 
Table 1a. Soil mechanical analysis at two depths

\begin{tabular}{ccccc}
\hline Soil depth $(\mathbf{c m})$ & Total sand $(\boldsymbol{\%})$ & Silt $(\boldsymbol{\%})$ & Clay $(\boldsymbol{\%})$ & Texture \\
\hline $0-15$ & 31.0 & 9.5 & 59.5 & Clay \\
$15-30$ & 29.0 & 11.0 & 60.0 & Clay \\
\hline
\end{tabular}

Table 1b.Soil chemical analysis at two depths

\begin{tabular}{|c|c|c|c|c|c|c|c|c|c|}
\hline \multirow{2}{*}{$\begin{array}{l}\text { Soil depth } \\
\text { (cm) }\end{array}$} & \multirow{2}{*}{\begin{tabular}{c} 
EC \\
Mmhos\} $\\
{\text { cm }}$ & \multirow[b]{2}{*}{ pH } & \multicolumn{3}{|c|}{ Soluble anions meq $\mathbf{L}$} & \multicolumn{4}{|c|}{ Soluble cations meq $\backslash \mathbf{L}$} \\
\hline & & & $\mathrm{HCO}_{3}^{-}$ & $\mathrm{Cl}^{-}$ & $\mathrm{SO}_{4}^{--}$ & $\mathbf{C a}^{++}$ & $\mathbf{M g}^{++}$ & $\mathbf{N a}^{+}$ & $\mathbf{K}^{+}$ \\
\hline $0-15$ & 12.1 & 7.7 & 19.5 & 52.6 & 10.0 & 22.1 & 15.3 & 60.1 & 0.46 \\
\hline $15-30$ & 11.0 & 7.5 & 17.4 & 50.5 & 9.4 & 20.0 & 15.0 & 52.3 & 0.81 \\
\hline
\end{tabular}}
\end{tabular}

using CMC solution (1\%) before application to get a thin, uniform coating of bacterial inoculum on seeds. Inoculated seeds were dried in shade before sowing (Samasegaranet al.,1982), untreated control seeds were maintained. After seed germination, each pot was inoculated with $10 \mathrm{ml}$ of microbial inoculum of an individual strain and mixture of them. Pots had been irrigated two times weekly. After 45 days of planting, the plants were harvested, and plant heights, fresh and dry weights were measured. A mechanical and chemical analysis of soil is presented in Table (1a,b).

\section{Field experiment:-}

Two growing seasons were conducted in 2015 and2016 at Sahle El-Tina North Sinai to study the potential of PSA mixture (Alcaligenes faecalis and Pseudomonas geniculate) and foliar application on the growth and productivity of selected sesame cultivar . Sahl El-Tina area is located within the extremely arid zone and suffering from mixed water and salinity problems. Organic manure and calcium superphosphate fertilizers were added during soil preparation at the rate of $20 \mathrm{~m}^{3}$ and $33 \mathrm{Kg} \mathrm{P}_{2} \mathrm{O}_{5} /$ fed respectively. Three equal doses of ammonium sulphate $(20.5 \% \mathrm{~N})$ were added at a rate of $66 \mathrm{~kg} \mathrm{~N} / \mathrm{fed}$. after thinning, 35 and50 days from sowing. Each experimental plot included 5 ridges, $60 \mathrm{~cm}$ apart with $3.5 \mathrm{~m}$ length, comprising an area of $10.5 \mathrm{~m}^{2}$ (1/400feddan). This area is irrigated through ElSalam Canal (Nile water mixed with agricultural drainage water at a rate of 1:1), chemical analysis of irrigated water was represented in Table (2).

For bio-treatments, seeds were coated with bacterial inoculum as previously mentioned ,untreated control seeds were maintained. Three foliar application were applied (Two concentrations of KCL 1\%, 2\% and without as a control). Foliar application treatments were carried out twice after 45 and 65 days from sowing using tween 20 as wetting agent.

The experiment included 6 treatments, which were the combination of three different foliar application treatments $\mathrm{X}$ two bio treatments. Treatments were arranged in a split plot design with three replications. Foliar application treatments occupied the main plots and bio treatments were in the sub plot .At harvest time, sesame plants were collected from each plot and the following characters were determined: plant height (cm), number of branches/ plant, number of capsules per plant, number of seeds / capsules, 1000 seed weight, seeds weight / plant, and seeds yield /fed. were recorded. Oil yield / fed. was determined using method of British pharmacopoeia (1936).

For chemical analysis of sesame seeds: Nitrogen was determined by micro-Kjeldahl method according to (Bremner and Mulvaney 1982) .Phosphorus and potassium were estimated using spectrophotometer and flame photometer, respectively as described in (Page et al. 1982). Fatty acids were determined using gas liquid chromatography (GLC) as fatty acid methyl esters (FAME) after acidic esterification of oil samples according to the method of Were et al. (2006).

For microbiological analysis: Nutrient and modified Bunt and Rovira media were used for counting of total microbes and phosphate dissolving bacteria from rhizosphere samples, respectively .Phosphatase activity in the rhizosphere regions were also estimated by Tabatabai and Brimner method (1969).

\section{Statistical analysis:}

Data were subjected to statistical analysis using the method described by (Snedecor, 1990). The least significant difference (L.S.D) was used to differentiate means according to (Waller and Duncan, 1969).

Table 2. Chemical analysis of El-Salam canal water

\begin{tabular}{|c|c|c|c|c|c|c|c|c|c|}
\hline \multirow[b]{2}{*}{ Water sample } & \multirow{2}{*}{$\begin{array}{c}\text { EC } \\
\text { Mmhos } \backslash \\
\text { cm } \\
\end{array}$} & \multirow[b]{2}{*}{ pH } & \multicolumn{3}{|c|}{ Soluble anions $\mathrm{dSm}^{-1}$} & \multicolumn{4}{|c|}{ Soluble cations $\mathrm{dSm}^{-1}$} \\
\hline & & & $\mathrm{HCO}_{3}^{-}$ & $\mathrm{Cl}^{-}$ & $\mathrm{SO}_{4}{ }^{--}$ & $\mathrm{Ca}^{++}$ & $\mathbf{M g}^{++}$ & $\mathrm{Na}^{+}$ & $\mathbf{K}^{+}$ \\
\hline Average & 1.44 & 7.5 & 9.1 & 17.3 & 6.4 & 6.0 & 8.0 & 18.6 & 28.0 \\
\hline
\end{tabular}




\section{RERSULTS}

\section{Evaluation of highly efficient phosphate dissolving bacteria under salt stress}

In the medium without salts $(0 \% \mathrm{NaCL})$, the selected four PSB were able to solubilize the insoluble form of phosphate in medium and achieve high concentration of soluble-P that ranged between 41.5 and 52.63 ppm among strains after 72 hours of incubation as in Fig.(1).The solubilization process at $(0 \% \mathrm{NaCL})$, was accompanied by a drop in initial $\mathrm{pH}$ from (6.9 at zero time to $4.6,4.5,4.5$ and 4.37 ) and high phosphatase enzyme activities $(0.38,0.42,0.58$ and $0.61 \mathrm{EU})$ for Azotobacter chroococcum, Alcaligene faecalis, Pseudomonas geniculate and B. subtilis, respectively. The inverse relationship observed between the $\mathrm{pH}$ and soluble-P concentration indicates that organic acid production by these PSB strains plays a significant role in the acidification of the medium facilitating the $\mathrm{P}$ solubilization (Chen et al.,2006).Studying the effect of salinity on solubilization process revealed that the maximum phosphate solubilization expressed as soluble-P concentration in the growth media was achieved at $1 \% \mathrm{NaCL}$ for Azotobacter chroococcum (0.39 EU) and $3 \%$ for others which mean that $A$. chroococcum was more sensitive to salinity than other

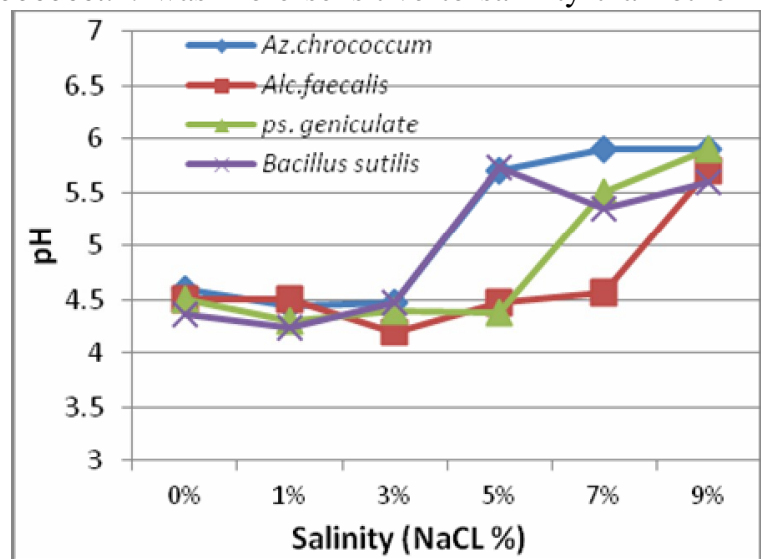

strains. For $\mathrm{pH}$, the highest reduction were achieved at $3 \% \mathrm{NaCL}$ for Alc. faecales and $1 \%$ for the rest strains. Concerning to phosphatase activity, increasing salinity from $0 \%$ to $9 \%$ NaCL had a negative effect on enzyme activity that the highest activity was recorded at $0 \%$ $\mathrm{NaCL}$ for all strains studied which decreased gradually with increasing salinity. The acidification does not seem to be the only mechanism of solubilization, as the ability to reduce the $\mathrm{pH}$ in some cases did not correlate with the ability to solubilize mineral phosphates (Subbarao, 1982). These mean that the solubilization is due to both reduction of $\mathrm{pH}$ and secretion of phosphatase enzymes. As a particular case, Gramnegative bacteria had shown to be capable of mobilize insoluble phosphate very efficiently; they produce gluconic acid during the extracellular oxidation of glucose catalyzed by quinoprotein glucose dehydrogenase (Goldstein,1994).Salinity up to $1 \%$ is very suitable for the growth, activity and effectiveness of phosphate solubilizing bacteria as Pseudomonas fluorescens, Bacillus thuringiensis, B. megaterium, Nocardi amesentrica, Aerobacter aerogenes, Azospirillum lipoferum and Azotobacter indicus while $4 \%$ salinity is still safe for their growth and activity (Sri,2015).

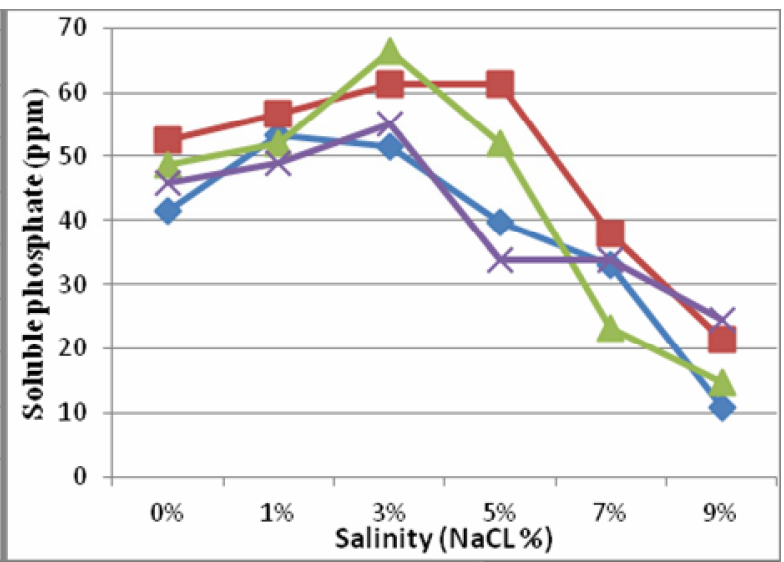

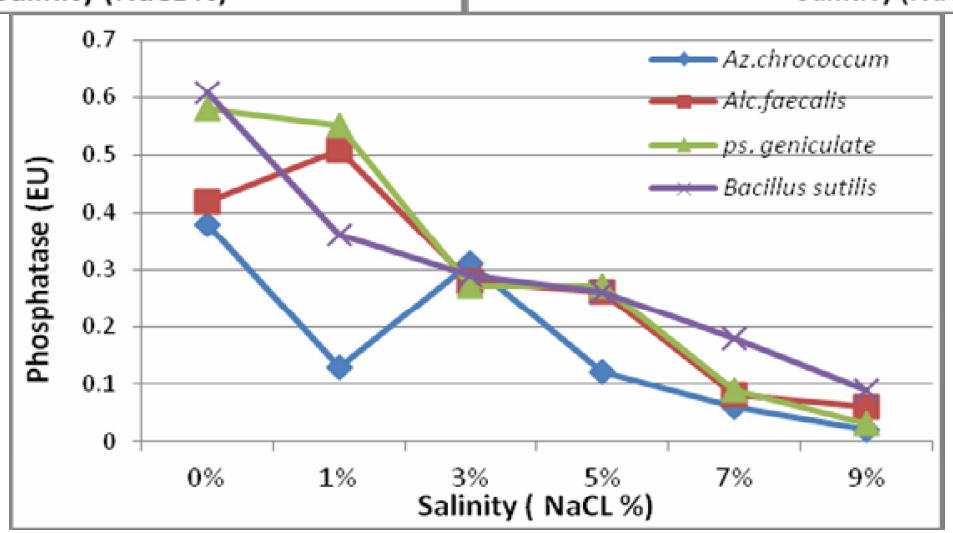

Figure 1.Effect of salinity on $\mathrm{pH}$, phosphate and phosphatase activity of four PSB 
At 3\% NaCL concentration ,Pseudomonas geniculate and Alcaligenes faecalis gave the maximum phosphate solubilization and so, they were selected as most efficient phosphates solubilizing bacteria under salt stress for further pot and field investigations. As recorded by Bikashet al. (2017), Alcaligenes faecalis exhibited maximum phosphate solubilizing activity to be $48 \mu \mathrm{g} / \mathrm{ml}$ with decreasing in the $\mathrm{pH}$ of the growth medium from 7.0 to 3.2 and high alkaline phosphatase activity.

Concerning to organic acids, HPLC analysis of bacterial broth grown at $1 \% \mathrm{NaCL}$ for Azotobacter chroococcum and 3\% for others ( The concentrations at which the selected strains exhibited the maximum solubilization activity ) revealed that the four strains secreted multiple organic acids as malic acid, formic acid, oxalic acid, lactic acid and shikimic acid with different quantities, while Alcaligenes faecalis and Pseudomonas geniculate also produce citric and succinic acids, only $B$. sutilis produce tartaric acid. In addition, all strains except Azotobacter chroococcum produced ascorbic acid as presented in Table ( 3 ). Alam et al. (2002) and Kumari et al. (2008) reported that malic, tartaric, oxalic, and citric acids have high capability to release soluble phosphate from insoluble tricalcium phosphate. During phosphate solubilization, Alcaligenes faecalis secreted various organic acids, such as oxalic acid (289 mg/L), citric acid ( $0.2 \mathrm{mg} / \mathrm{L})$, malic acid $(0.3 \mathrm{mg} / \mathrm{L})$, succinic acid $(0.5 \mathrm{mg} / \mathrm{L})$ and acetic acid $(0.4 \mathrm{mg} / \mathrm{L})$ in the broth culture (Bikash et al. 2017 ).

\section{Pot Experiment:-}

Evaluation of sesame cultivars under salt stress revealed significant differences among all cultivars for all traits recorded. While Giza32 cultivar recorded the highest plant height, fresh and dry weight $(34.16 \mathrm{~cm}$, 24.6 and $7.07 \mathrm{gm}$ ), respectively, Zail Elgamal cultivar recorded the lowest one ( $34.16 \mathrm{~cm}, 24.6$ and $7.07 \mathrm{gm}$ ) as in Table (4). This means that Giza32 was the most resistant cultivar to salinity followed by Shandaweel and Sohag while ZE cultivar was the lowest one. These results may be due to the differences in genetic background between the four studied cultivars. Difference in sensitivity and response of plants to $\mathrm{NaCl}$ at cultivars level largely depends upon genetic constitution of the plants (Yeo and Flowers, 1986;Garcia-Reina et al., 1988).

For biotreatments studied, Ps. geniculate was more efficient than Alc. faecalis for enhancing all sesame growth traits. Also, mixture of Pseudomonas geniculate and Alcaligenes faecalis gave the highest results for all traits recorded compared to each one separately as indicated in Table (4). Pseudomonas geniculate characterized as plant growth-promoting significantly enhanced shoot and root weight of chickpea (Subramaniamet al. 2015). Alcaligene faecalis showed significantly taller plant height, more number of leaves, higher numbers of pods and plant dry weight of soybean compared to un-inoculated ones(Nandiniet al. , 2014). From previous data, both Giza31 cultivar and mixed bio-fertilizers were selected for further investigation in two successive field experiments.

\section{Field experiments}

Application of mixed bio treatment as seed coating increased the seeds yield /fed. reaching 452.6 and 472.5 $\mathrm{Kg} /$ fed. compared to untreated plants in first and second season, respectively. This might be attributable to the increase in the number of branches, number of capsules /plant as tabulated in Table (5), number of seeds / capsules and 1000 seed weight (g) compared to untreated ones. Sabannavarand Lakshman (2009) mentioned that bio fertilization increased plant growth, number of capsules/plant and seed yield of sesame.

Table 3. Organic acids secreted by four phosphate solubilizing strains under salinity condition

\begin{tabular}{|c|c|c|c|c|c|}
\hline \multirow{2}{*}{$\begin{array}{c}\text { Standard } \\
\text { organic acids } \\
(\mathbf{m g} / \mathbf{1 0 0 m l})\end{array}$} & \multirow{2}{*}{$\begin{array}{c}\text { RT } \\
(\mathbf{m i n})\end{array}$} & \multicolumn{4}{|c|}{ Organic acids $(\mathrm{mg} / \mathbf{1 0 0 m l})$} \\
\hline & & $\begin{array}{c}\text { Alcaligenes } \\
\text { faecalis }\end{array}$ & $\begin{array}{c}\text { Bacillus } \\
\text { subtilis }\end{array}$ & $\begin{array}{l}\text { Azotobacter } \\
\text { chroococcum }\end{array}$ & $\begin{array}{c}\text { Pseudomonas } \\
\text { geniculate }\end{array}$ \\
\hline Ascorbic acid & 6.569 & 0.38 & 0.365 & - & 0.46 \\
\hline Citric acid & 11.153 & 8.2 & - & - & 8.05 \\
\hline Formic acid & 5.346 & 3.2 & 9.465 & 4.437 & $3.9-$ \\
\hline Lactic acid & 7.471 & 4.65 & 3.722 & 3.015 & 4.27 \\
\hline Malic acid & 8.717 & 5.7 & 4.3 & 5.1 & 6.33 \\
\hline Oxalic acid & 4.413 & 10.98 & 0.771 & 2.435 & 9.96 \\
\hline Shikimic acid & 6.342 & 0.14 & 0.046 & 0.045 & 0.09 \\
\hline Succinic acid & 12.610 & 4.53 & - & - & 3.9 \\
\hline Tartaric acid & 5.013 & - & 4.077 & - & - \\
\hline
\end{tabular}


Table 4.Evaluation of different sesame cultivars and biofertilizer on different growth traits of sesame plant in pot experiment

\begin{tabular}{|c|c|c|c|c|}
\hline \multicolumn{2}{|c|}{ Treatments } & \multicolumn{3}{|c|}{ Growth Characteristics } \\
\hline Cultivar & Biotreatments & $\begin{array}{l}\text { Plant height } \\
\text { (cm ) }\end{array}$ & $\begin{array}{c}\text { Fresh weight } \\
(\mathrm{gm})\end{array}$ & $\begin{array}{l}\text { Dry weight } \\
\text { (gm) }\end{array}$ \\
\hline \multicolumn{5}{|c|}{ Effect of Cultivar } \\
\hline \multicolumn{2}{|c|}{ Sohag } & 32 & 31.42 & 6.34 \\
\hline \multicolumn{2}{|c|}{ Giza32 } & 34.16 & 24.6 & 7.07 \\
\hline \multicolumn{2}{|c|}{ Shandaweel } & 32.25 & 18.55 & 5.82 \\
\hline \multicolumn{2}{|c|}{ Zail Elgamal } & 28.66 & 18.41 & 5.16 \\
\hline \multicolumn{2}{|c|}{ LSD } & 1.46 & 0.953 & 0.317 \\
\hline \multicolumn{5}{|c|}{ Effect of biofertilizer } \\
\hline \multicolumn{2}{|c|}{ Without } & 28.58 & 17.25 & 5.31 \\
\hline \multicolumn{2}{|c|}{ Alc. faecalis } & 32.41 & 22.96 & 5.84 \\
\hline \multicolumn{2}{|c|}{ Ps. geniculate } & 32.75 & 25.45 & 6.4 \\
\hline \multicolumn{2}{|c|}{ Mixture } & 33.4 & 27.4 & 6.85 \\
\hline \multicolumn{2}{|c|}{ LSD } & 1.54 & 1.52 & 0.14 \\
\hline \multicolumn{5}{|c|}{ Effect of interaction } \\
\hline \multirow[t]{4}{*}{ Sohag } & Without & 29.5 & 16.7 & 5.3 \\
\hline & Alc. faecalis & 33 & 27.1 & 6.4 \\
\hline & Ps. geniculate & 32.8 & 25.9 & 6.4 \\
\hline & Mixture & 33.1 & 28.8 & 7.1 \\
\hline \multirow[t]{4}{*}{ Giza32 } & Without & 30.8 & 22.2 & 6.0 \\
\hline & Alc. faecalis & 34.8 & 29.2 & 6.4 \\
\hline & Ps. geniculate & 35.7 & 37.1 & 7.8 \\
\hline & Mixture & 35.8 & 37.2 & 7.9 \\
\hline \multirow[t]{4}{*}{ Shandaweel } & Without & 28.1 & 13.8 & 5.4 \\
\hline & Alc. faecalis & 33.4 & 17.5 & 5.7 \\
\hline & Ps. geniculate & 33.2 & 19.5 & 6 \\
\hline & Mixture & 34.8 & 23.3 & 6.1 \\
\hline \multirow[t]{5}{*}{ Zail Elgamal } & Without & 26.4 & 16.2 & 4.4 \\
\hline & Alc. faecalis & 28.7 & 17.3 & 4.7 \\
\hline & Ps. geniculate & 29.3 & 19.2 & 5.2 \\
\hline & Mixture & 30.4 & 21.2 & 6.2 \\
\hline & 0.05 & 1.32 & 1.03 & 0.16 \\
\hline
\end{tabular}

Concerning to foliar spraying of potassium, significant increases in yield and all of its components i.e. number of branches, number of capsules /plant, number of seeds / capsules, 1000 seed weight $(\mathrm{g})$, seeds weight / plant $(\mathrm{g})$, seeds yield /fed. $(\mathrm{kg})$ were recorded with spraying different concentrations of KCL $(1$ and 2 $\%$ ) compared with the control. Khan et al. (2006) carried out experiments to evaluate the response of wheat to foliar application of $\mathrm{N}$ and $\mathrm{K}$ and observed that both $\mathrm{KNO}_{3}$ and KCL used as foliar spray were proven to be equally effective in increasing wheat yield. Abaye (1998) showed that supplementing potassium by any method increased lint yields compared with that of untreated control.

Concerning the interaction between bio-fertilizers and foliar application, plant height number of branches, number of capsules /plant, number of seeds / capsules, 1000 seed weight $(\mathrm{g})$, seeds weight / plant $(\mathrm{g})$, seeds

yield /fed. ( $\mathrm{kg}$ ) and oil\% of sesame plants were significantly increased with applying both bio treatment and foliar application under saline soil conditions. Elwan (2010) mentioned that spraying of di-potassium hydrogen orthophosphate $\left(\mathrm{K}_{2} \mathrm{HPO}_{4}\right)$ ameliorated the negative effects of salinity on plant growth, fruit yield and fruit total sugar content of egg plant.Hussain et al. (2015) indicated that the effects of salinity were ameliorated by the application of $\mathrm{K}$ and $\mathrm{P}$ fertilizers resulting in higher yield. Shehu et al. (2010) observed that number of capsules/plant and seed weight/plant were increased by adding potassium fertilization (22.5 and $45 \mathrm{~kg} \mathrm{~K} \mathrm{~K}_{2} \mathrm{O} / \mathrm{ha}$ ). Under farm field conditions, Pseudomonas geniculata significantly enhanced nodule number and weight, shoot, and root weight, stover and grain yield and total dry matter of chickpea (Subramaniamet al., 2015). 
Table 5. Effect of Bio-fertilizer and foliar application treatments on the yield of sesame plant and its components

\begin{tabular}{|c|c|c|c|c|c|c|c|c|c|}
\hline \multicolumn{2}{|c|}{ Treatments } & $\begin{array}{c}\text { Plant } \\
\text { height } \\
\text { (cm ) }\end{array}$ & $\begin{array}{c}\text { Number } \\
\text { of } \\
\text { branches } \\
\text { / plant }\end{array}$ & $\begin{array}{c}\text { Number } \\
\text { of } \\
\text { capsules } \\
\text { /plant }\end{array}$ & $\begin{array}{l}\text { Number } \\
\text { of seeds/ } \\
\text { capsules }\end{array}$ & $\begin{array}{c}1000 \\
\text { seeds } \\
\text { weight } \\
\text { (g) }\end{array}$ & $\begin{array}{c}\text { Seeds } \\
\text { weight } \\
\text { / plant } \\
\text { (g) }\end{array}$ & $\begin{array}{c}\text { Seeds } \\
\text { yield } \\
\text { /fed. } \\
\text { (Kg/fed.) }\end{array}$ & $\begin{array}{c}\text { Oil } \\
\text { Yield } \\
\text { (Kg/fed) }\end{array}$ \\
\hline \multicolumn{10}{|c|}{ Season 2015} \\
\hline \multicolumn{10}{|c|}{ Effect of Biofertilizar:- } \\
\hline \multicolumn{2}{|c|}{ Control } & 120.6 & 3.2 & 52.7 & 49.7 & 3.5 & 13.1 & 371.1 & 190.0 \\
\hline \multicolumn{2}{|l|}{ Bio.1 } & 132.5 & 3.9 & 58.2 & 55.8 & 4.2 & 16.0 & 452.6 & 225.4 \\
\hline \multicolumn{2}{|c|}{ L.S.D. } & 1.57 & 0.36 & 0.23 & 0.70 & 0.06 & 0.44 & 33.15 & 15.56 \\
\hline \multicolumn{10}{|c|}{ Effect of foliar application } \\
\hline \multicolumn{2}{|c|}{ Control } & 112.85 & 2.8 & 49.00 & 45.55 & 3.1 & 12.05 & 360.85 & 166.05 \\
\hline \multicolumn{2}{|l|}{ KCL $1 \%$} & 129.60 & 3.7 & 56.35 & 53.50 & 4.0 & 14.85 & 416.15 & 213.60 \\
\hline \multicolumn{2}{|c|}{ KCL $2 \%$} & 137.35 & 4.2 & 60.95 & 59.20 & 4.4 & 16.70 & 458.6 & 243.50 \\
\hline \multirow{2}{*}{\multicolumn{2}{|c|}{$\begin{array}{l}\text { L.S.D. } \\
\text { Effect of interaction: }\end{array}$}} & 1.26 & 0.05 & 0.62 & 0.78 & 0.14 & 0.44 & 30.09 & 12.38 \\
\hline & & \multicolumn{8}{|c|}{ Bio. $\quad$ Foliar } \\
\hline \multirow[t]{3}{*}{ Without } & Control & 109.2 & 2.6 & 46.4 & 42.6 & 2.6 & 11.5 & 325.2 & 145.6 \\
\hline & $\begin{array}{l}\text { KCL1 } \\
\%\end{array}$ & 120.6 & 3.2 & 53.2 & 50.2 & 3.8 & 13.2 & 385.5 & 198.6 \\
\hline & $\begin{array}{l}\text { KCL2 } \\
\%\end{array}$ & 132.2 & 3.8 & 58.5 & 56.2 & 4.0 & 14.6 & 402.6 & 225.8 \\
\hline \multirow[t]{3}{*}{ Mixture } & Control & 116.5 & 3.0 & 51.6 & 48.5 & 3.6 & 12.6 & 396.5 & 186.5 \\
\hline & $\begin{array}{l}\text { KCL1 } \\
\%\end{array}$ & 138.6 & 4.2 & 59.5 & 56.8 & 4.2 & 16.5 & 446.8 & 228.6 \\
\hline & $\begin{array}{l}\text { KCL2 } \\
\%\end{array}$ & 142.5 & 4.6 & 63.4 & 62.2 & 4.8 & 18.8 & 514.6 & 261.2 \\
\hline \multirow{2}{*}{\multicolumn{2}{|c|}{ L.S.D. }} & 1.43 & 0.03 & 0.21 & 0.80 & 0.10 & 0.38 & 29.55 & 17.43 \\
\hline & & & & Seas & 2016 & & & & \\
\hline \multicolumn{10}{|c|}{ Effect of Biofertilizar:- } \\
\hline \multicolumn{2}{|c|}{ Control } & 118.6 & 3.3 & 54.8 & 51.2 & 3.53 & 14.7 & 383.8 & 195.7 \\
\hline \multicolumn{2}{|l|}{ Bio. 1} & 135.6 & 4.1 & 59.3 & 57.8 & 4.30 & 16.7 & 472.5 & 233.1 \\
\hline \multicolumn{2}{|c|}{ L.S.D. } & 1.22 & 0.20 & 0.34 & 0.65 & 0.26 & 0.30 & 31.16 & 11.07 \\
\hline \multicolumn{10}{|c|}{ Effect of foliar application } \\
\hline \multicolumn{2}{|c|}{ Control } & 109.00 & 3.0 & 48.15 & 46.85 & 3.05 & 12.9 & 371.0 & 168.6 \\
\hline \multicolumn{2}{|l|}{ KCL $1 \%$} & 133.05 & 3.8 & 59.10 & 56.40 & 4.00 & 16.1 & 437.1 & 222.4 \\
\hline \multicolumn{2}{|l|}{$\mathrm{KCL} 2 \%$} & 139.30 & 4.4 & 63.80 & 60.25 & 4.70 & 18.1 & 476.5 & 252.2 \\
\hline \multicolumn{2}{|c|}{ L.S.D. } & 1.19 & 0.13 & 1.04 & 1.50 & 0.22 & 1.09 & 26.40 & 22.26 \\
\hline \multicolumn{10}{|c|}{ Effect of Interaction :- } \\
\hline \multicolumn{10}{|c|}{ Bio. $\quad$ Folair } \\
\hline & $\begin{array}{l}\text { KCL1 } \\
\%\end{array}$ & 122.5 & 3.2 & 55.6 & 53.6 & 3.8 & 15.4 & 392.6 & 204.6 \\
\hline & $\begin{array}{l}\text { KCL2 } \\
\%\end{array}$ & 134.8 & 4.0 & 61.2 & 56.5 & 4.2 & 16.0 & 422.5 & 234.2 \\
\hline Mixture & control & 119.4 & 3.2 & 48.8 & 50.2 & 3.5 & 13.2 & 405.5 & 189.0 \\
\hline & $\begin{array}{l}\text { KCL1 } \\
\%\end{array}$ & 143.6 & 4.4 & 62.6 & 59.2 & 4.2 & 16.8 & 481.6 & 240.2 \\
\hline & $\begin{array}{l}\text { KCL2 } \\
\%\end{array}$ & 143.8 & 4.8 & 66.4 & 64.0 & 5.2 & 20.2 & 530.5 & 270.2 \\
\hline L.S.D. & & 1.35 & 0.31 & 1.00 & 1.21 & 0.11 & 0.80 & 8.02 & 20.22 \\
\hline
\end{tabular}


Similar trends were observed for oil content in sesame seeds that interaction between mixed bio treatment and foliar application of $2 \% \mathrm{KCL}$ recorded the highest results reaching 261.2 and $270.2 \mathrm{Kg} / \mathrm{fed}$. for the first and second season compared to controls (190 and $195.7 \mathrm{Kg} / \mathrm{fed}$. ), respectively.

As indicated in Table (6), mixed biofertilizer was found to be highly significantly effective in increasing NPK values of seed $(3.42,0.55$ and $1.07 \%)$ respectively comparing to untreated ones in second season. Quesni et al. (2010) concluded that biofertilizers decreased the hazard effect of salinity and exerted a favorable effect on growth and N, P and K concentration in Schefflera arboricola L. seedlings irrigated with saline water.

For foliar application, spraying plants with $2 \% \mathrm{KCL}$ resulted a significant increase in chemical contents of seeds, recorded highest values $(0.55$ and $1.105 \%)$ for $\mathrm{P}$ and $\mathrm{K}$, respectively, comparing to control in the second season. On other hand, application of $\mathrm{K}$ had no significant increase in $\mathrm{N}$ content of seed in two seasons .Foliar feeding of a nutrient may actually promote root absorption of the same nutrient (Oosterhuis, 1998) or other nutrients through improving root growth and increasing nutrients uptake (El-Fouly and El-Sayed, 1997). Furthermore, the highest significant increase in $\mathrm{N}, \mathrm{P}$ and $\mathrm{K}$ concentrations of sesame seeds was recorded by the interaction of biofertilizer and foliar application in both seasons. Generally the increases in macronutrient concentrations in seeds may be due to the availability of them in the soil as a result of decreasing soil $\mathrm{pH}$ and salinity caused by the action of organic materials or biofertilizer (Antoun et al. 2010).Under field condition, Pseudomonas geniculate significantly enhanced grain yield, total nitrogen and available phosphorus of chickpea (Subramaniam et al., 2015).

\section{Fatty-acids of sesame oil :}

Composition of sesame oil fatty acids under different treatments are presented in Table (7). Results indicated that the highest fatty-acid percentage was as follows: Oleic, linoleic and palmitic acids. Data also indicated that the unsaturated fatty acid constituents in sesame oil were oleic, linoleic and linolenic acid while the predominant saturated ones were palmitic and stearic acids. As illustrated by Nzikou et al. (2009), the main saturated fatty acids in sesame seed oil were palmitic $(8.67 \%)$, stearic $(5.56 \%)$ acids with small arachidic acid $(0.8 \%)$. Oleic and linoleic acids were the major fatty acids of sesame oil which reported in large amounts in the oils of all genotypes, palmitic and stearic acids were reported as predominant saturated fatty acids while arachidic acid as minimum ones (Kurt et al., 2016). Application of mixed bacterial treatment showed slightly increase in all saturated fatty acids compared to the control (without biofertilizer) while contents of Linoleic and Linolenic acids were decreased under the same conditions. Concerning to foliar application of $\mathrm{KCL}$, increase in oleic acid and all saturated fatty acids compared to the control were detected. In addition, the decrease of linoleic and linolenic acid were detected under the same foliar application.

Table 6. Effect of biofertilizer and foliar application treatments on chemical components of sesame seeds

\begin{tabular}{|c|c|c|c|c|c|c|c|}
\hline \multirow{3}{*}{\multicolumn{2}{|c|}{ Treatments }} & \multicolumn{6}{|c|}{ Chemical constituents of sesame seeds } \\
\hline & & \multicolumn{3}{|c|}{ Season 1} & \multicolumn{3}{|c|}{ Season 2} \\
\hline & & N\% & $\mathbf{P \%}$ & $\mathbf{K} \%$ & $\mathbf{N \%}$ & $\mathbf{P \%}$ & $\mathbf{K} \%$ \\
\hline \multicolumn{8}{|c|}{ Effect of Biofertilizar:- } \\
\hline \multicolumn{2}{|c|}{ Control } & 3.2 & 0.47 & 1.02 & 3.23 & 0.5 & 1.03 \\
\hline \multicolumn{2}{|c|}{ Biotreatment } & 3.12 & 0.546 & 1.05 & 3.42 & 0.55 & 1.07 \\
\hline \multicolumn{2}{|c|}{ L.S.D. } & 0.1 & 0.021 & 0.06 & 0.051 & 0.021 & 0.011 \\
\hline \multicolumn{8}{|c|}{ Effect of foliar application } \\
\hline \multicolumn{2}{|c|}{ Control } & 3.15 & 0.48 & 0.975 & 3.31 & 0.495 & 0.98 \\
\hline \multicolumn{2}{|c|}{$\mathrm{KCL}_{1} \%$} & 3.16 & 0.52 & 1.05 & 3.33 & 0.53 & 1.07 \\
\hline \multicolumn{2}{|c|}{$\mathrm{KCL}_{2} \%$} & 3.175 & 0.53 & 1.08 & 3.34 & 0.55 & 1.105 \\
\hline \multicolumn{2}{|c|}{ L.S.D. } & 0.11 & 0.026 & 0.074 & 0.063 & 0.025 & 0.014 \\
\hline \multicolumn{8}{|c|}{ Effect of interaction:- } \\
\hline \multirow[t]{2}{*}{ Biotreatment } & Folair & & & & & & \\
\hline & Control & 3.1 & 0.45 & 0.94 & 3.23 & 0.46 & 0.94 \\
\hline \multirow[t]{3}{*}{ Without } & $\mathrm{KCL}_{1} \%$ & 3.13 & 0.49 & 1.05 & 3.24 & 0.51 & 1.06 \\
\hline & $\mathrm{KCL}_{2} \%$ & 3.14 & 0.49 & 1.08 & 3.24 & 0.53 & 1.09 \\
\hline & Control & 3.2 & 0.51 & 1.01 & 3.4 & 0.53 & 1.02 \\
\hline \multirow[t]{2}{*}{ Mixture } & $\mathrm{KCL}_{1} \%$ & 3.2 & 0.56 & 1.06 & 3.43 & 0.55 & 1.08 \\
\hline & $\mathrm{KCL}_{2} \%$ & 3.21 & 0.57 & 1.08 & 3.44 & 0.57 & 1.12 \\
\hline L.S.D. & & 0.12 & 0.021 & 0.076 & 0.068 & 0.024 & 0.012 \\
\hline
\end{tabular}


Table 7. Effect of Bio fertilizer and foliar application treatments on fatty acids composition of sesame seeds

\begin{tabular}{|c|c|c|c|c|c|c|c|c|c|c|c|c|}
\hline \multirow{2}{*}{\multicolumn{2}{|c|}{ Treatments }} & \multicolumn{11}{|c|}{ Fatty acids composition (\%) } \\
\hline & & \multicolumn{4}{|c|}{ Saturated } & & \multicolumn{3}{|c|}{ Unsaturated } & \multirow[b]{2}{*}{ 吾 } & \multirow[b]{2}{*}{ 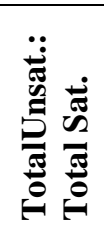 } & \multirow[b]{2}{*}{$\begin{array}{l}.0 \\
\end{array}$} \\
\hline Bio. & Foliar & $\frac{\mathscr{y}}{\frac{m}{2}}$ & 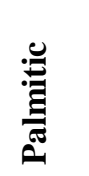 & $\frac{\mathscr{E}}{\mathscr{\varpi}}$ & & $\stackrel{\bar{\sigma}}{0}$ & $\frac{\frac{u}{\pi}}{0}$ & 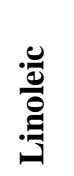 & 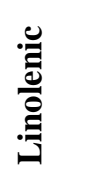 & & & \\
\hline \multirow{3}{*}{ Without } & Control & 0.23 & 11.2 & 3.8 & 0.62 & 15.85 & 45.74 & 36.9 & 0.64 & 83.28 & 5.25 & 1.23 \\
\hline & KCL $1 \%$ & 0.32 & 11.6 & 4.2 & 0.73 & 16.85 & 46.12 & 36.4 & 0.37 & 82.89 & 4.91 & 1.26 \\
\hline & KCL2 \% & 0.33 & 11.9 & 4.3 & 0.74 & 17.27 & 46.20 & 36.1 & 0.39 & 82.69 & 4.78 & 1.27 \\
\hline \multirow{3}{*}{ Mixture } & Control & 0.25 & 11.4 & 4.0 & 0.64 & 16.29 & 45.63 & 36.9 & 0.41 & 82.94 & 5.09 & 1.23 \\
\hline & KCL $1 \%$ & 0.37 & 12.2 & 4.5 & 0.77 & 17.84 & 45.77 & 35.8 & 0.36 & 81.93 & 4.59 & 1.27 \\
\hline & KCL2 $\%$ & 0.37 & 12.5 & 4.6 & 0.76 & 18.23 & 46.25 & 35.1 & 0.38 & 81.73 & 4.48 & 1.31 \\
\hline
\end{tabular}

Table 8. Effect of Bio fertilizer and foliar applications on microbiological characteristics of sesame rhizosphere

\begin{tabular}{|c|c|c|c|c|c|c|c|}
\hline \multirow{2}{*}{\multicolumn{2}{|c|}{ Treatments }} & \multicolumn{3}{|c|}{ Season 1} & \multicolumn{3}{|c|}{ Season 2} \\
\hline & & \multirow{2}{*}{$\begin{array}{c}\text { Total } \\
\text { microbial } \\
\text { count } \times 10^{5} \\
\text { CFU g } \mathbf{g}^{-1} \\
\text { dry soil }\end{array}$} & \multirow{2}{*}{$\begin{array}{c}\text { Phosphate } \\
\text { Dissolving } \\
\text { Bacteria } \\
{\text { x } 10^{3} \mathrm{CFU}} \\
\mathrm{g}^{-1} \text { dry soil }\end{array}$} & \multirow{2}{*}{$\begin{array}{c}\text { Phosphatase } \\
\text { enzyme } \\
\text { (EU) }\end{array}$} & \multirow{2}{*}{$\begin{array}{c}\text { Total } \\
\text { microbial } \\
\text { count x10 } \\
\text { CFU g } \mathbf{g}^{-1} \\
\text { dry soil }\end{array}$} & \multirow{2}{*}{$\begin{array}{c}\text { Phosphate } \\
\text { Dissolving } \\
\text { Bacteria } \\
\text { x 10 } 10^{3} \text { CFU } \\
\text { g }^{-1} \text { dry soil }\end{array}$} & \multirow{2}{*}{$\begin{array}{l}\text { Phosphatase } \\
\text { enzyme } \\
\text { (EU) }\end{array}$} \\
\hline Bio & Foliar & & & & & & \\
\hline \multirow{3}{*}{$\begin{array}{c}\text { Without } \\
\text { Bio }\end{array}$} & Control & 82 & 2.5 & $0.52 \mathrm{~b}$ & 98 & 2.8 & $0.54 \mathrm{~b}$ \\
\hline & KCL $1 \%$ & 102 & 2.6 & $0.56 \mathrm{~b}$ & 104 & 3.4 & $0.54 \mathrm{~b}$ \\
\hline & KCL $2 \%$ & 104 & 2.5 & $0.56 \mathrm{~b}$ & 1.6 & 3.5 & $0.56 \mathrm{~b}$ \\
\hline \multirow[t]{4}{*}{ Mixture } & Control & 180 & 7.3 & $0.67 \mathrm{a}$ & 265 & 9.1 & $0.69 \mathrm{a}$ \\
\hline & KCL $1 \%$ & 192 & 7.5 & $0.66 \mathrm{a}$ & 269 & 9.4 & $0.69 \mathrm{a}$ \\
\hline & KCL $2 \%$ & 191 & 7.5 & $0.68 \mathrm{a}$ & 268 & 9.5 & $0.71 \mathrm{a}$ \\
\hline & \multicolumn{3}{|c|}{ L.S.D } & 0.039 & & & 0.035 \\
\hline
\end{tabular}

- Initial total microbial counts was $63 \times 10^{5} \mathrm{cfu} \mathrm{g}^{-1}$ dry soil

- Initial Phosphate Dissolving Bacteria $1.9 \times 10^{3} \mathrm{cfu} \mathrm{g}^{-1}$ dry soil

- Initial phosphatase enzyme was 0.34 (EU)

\section{Microbiological activities}

Both total microbial populations and phosphate dissolving bacterial counts had increased in all treatments over the initial population prior to field experiments. Mixed bio-treatment with Pseudomonas geniculate and Alcaligenes faecalis recorded the highest counts of total and phosphate dissolving bacteria compared to that without bacterial inoculation in both seasons as indicated in Table (8). Foliar application of KCL have no remarkable increase on total microbial community or phosphate dissolving bacteria in the rhizosphere region. Ashrafuzzamanet al. (2009) reported that inoculation with the plant growth promoting rhizobacteria had stimulation effect on the population of rhizosphere microorganism (RMO) and increased their numbers by more than $50 \%$ at the end of the experiment comparing with the number recorded before planting.

Concerning to phosphatase enzyme, a dual effect of bacterial and foliar applications produced the highest significant activity of the enzyme in the rhizosphere regions reaching $0.71 \mathrm{EU}$ followed by bacterial inoculation only which recorded $0.69 \mathrm{EU}$ in second season of planting. On the other hand, application of $\mathrm{KCL}$ at both concentrations have no significant effect on the enzyme activity at the rhizosphere regions. Many enzymes as phosphatase are produced constitutively by microbes and generate low concentrations of microbially-available products that induce additional enzyme synthesis (Koroljova et al., 1998; Klonowska et al., 2002).

\section{CONCLUSION}

It could be concluded that, while increasing salinity had a negative effect on phosphatase activity enzyme activity which decreased gradually with increasing salinity, solubilization expressed as soluble-P concentration in the growth media had achieved at $1 \%$ $\mathrm{NaCL}$ and $3 \%$ for bacterial strains under investigation and this may be attributed to the reduction in the $\mathrm{pH}$ of the growth media. Giza32 cultivar of sesame was the most resistant cultivar to salinity followed by 
Shandaweel and Sohag while ZE cultivar was the least one. Both mixed biofertilizer of Pseudomonas geniculate and Alcaligenes faecalis and foliar application of KCL had significant positive effect on the sesame yield, oil content and chemical constituents of sesame seeds under saline condition.

\section{REFERENCES}

Abaye Ozzie, A. 1998. Effect of method and time of potassium application on cotton lint yield. Better Crops. 82(2): 25-27.

Abd-Alla, M. H. 1994. Phosphatases and the utilization of organic phosphorus by Rhizobium leguminosa. Letters in Applied Microbiology, 18 (5): 294-296.

Aktas, A.H., S. Sen, M. Yilmager and E. Cubuk. 2005. Determination of carboxylic acid in apple juice by RP HPLC .Iran .J. Chemical Eng. 24(1): 1-6.

Alam, S., S. Khalil, N. Ayub and M. Rashid. 2002. In vitro solubilization of inorganic phosphate by phosphate solubilizing microorganisms (PSM) from maize rhizosphere. Int. J. Agri. Biol. 4: 454-458.

Antoun, L.W., M.Z. Sahar and H.R. Hanaa. 2010.Influence of compost, $\mathrm{N}$-mineral and humic acid on yield and chemical composition of wheat plants. J. Soil Sci. and Agric. Engi. Mansoura Univ. 1(11): 1131-1143.

Ashrafuzzaman, M., A.H.R.I.M. Farid, H.M.d. Anamul, I.S.M. Zahurul, S.M. Shahidullah and S. Meon. 2009. Efficiency of plant growth-promoting rhizobacteria (PGPR) for the enhancement of rice growth. African Jornal of Biotechnology. 8 (7): 1247-1252.

Bikash, C. B. , H. Yadavb, S.K. Singhc, B.K. Sethid, R.R. Mishrad, S. Kumarie and H. Thatoi. 2017. Alkaline phosphatase activity of a phosphate solubilizing Alcaligenes faecalis, isolated from Mangrove soil Biotechnology Research and Innovation In press. Available online 2

Bremner, J. M. and C. S. Mulvaney. 1982.Nitrogen. In: Page, A.L., Miller, R.H. and Keeney, D.R. (Eds.), Methods of soil analysis. Part 2, Chemical and microbiological properties. Agronomy 9, Soc. Agron., Madison, Wisconsin. pp. 595-624.

British, P. 1936. Determination of volatile oil in drugs. Published by the pharmaceutical press, London.

Chen, Y.P., P.D. Rekha, A.B. Arun, F.T. Shen, W.A. Lai and C.C. Young. 2006. Phosphate solubilizing bacteria from subtropical soil and their tricalcium phosphate solubilizing abilities. Appl Soil Ecol. 34:33-41.

Delvasto, P., A.Valverde, J.M. Igual., J.A. Munoz, F.Gonzalez, M.L.Blazquez and C. Garcia-Balboa. 2006. Diversity and activity of phosphate bioleaching bacteria from a high phosphorous iron-ore. Soil Biology and Biochemistry. 38: 2645-2654.

El-Fouly, M.M. and A.A. El-Sayed. 1997. Foliar fertilization: An environmentally friendly application of fertilizers. Dahlia Greidinger International Symposium on
"Fertilization and Environment" 24-27 March, Haifa, Israel, John. I.(ed.): 346-357.

El-Latif, K.M.A., E.A.M. Osman, R. Abdullah and N.A. El Kader. 2011. Response of potato plants to potassium fertilizer rates and soil moisture deficit. Adv. Applied Sci. Res. 2: 388-397.

Elwan, M.W.M., 2010. Ameliorative effects of di-potassium hydrogen orthophosphate on salt stressed eggplant. J. Plant Nutr. 33: 1593-1604.

Faostat database. 2012. Food and Agriculture Organization of the United Nations.

Froment M.A., D. Turley and L.V. Collings. 2000. Effect of nutrition on growth and oil quality in linseed. Tests of Agrochemicals and Cultivars No. 21: 29-30.

Garcia-Reina, G., V. Moreno and A. Luque. 1988.Selection for $\mathrm{NaCl}$ tolerance in cell culture of three canary island tomato land races. I. Recovery of tolerant plantlets from $\mathrm{NaCl}$ tolerant cell strains. J. Plant Physiol. 133:1-6.

Goldstein, A.H. 1994. Involvement of the quinoprotein glucose dehydrogenises in the solubilization of exogenous phosphates by gram-negative bacteria. In: A. Torriani Gorini, E.Yagil and S. Silver (eds.), Phosphate in Microorganisms: Cellular and Molecular Biology.ASM Press, Washington. D.C. 197-203.

Grattan, S.R. and C.M. Grieve. 1999. Mineral nutrient acquisition and response of plants grown in saline environments. In: Handbook of Plant and Crop Stress, M. Pessarakli, (Ed.), Marcel Dekker Press Inc. New York. pp. 203-229.

Hussain, Z., R.A. Khattak, I. Fareed, M. Irshad and Q. Mahmood. 2015.Interaction of phosphorus and potassium on maize (Zea mays L.) in saline-sodic soil.Agric Sci. 7(3): 66-78.

Isherword, K.F. 1998. Fertilizer use and environment. In: N. Ahmed and A. Hamid (eds.), Proc. Symp. Plant Nutrition Management for Sustainable Agricultural Growth. NFDC, Islamabad. pp: 57-76.

Jadhav, G.G., D.S. Salunkhe, D.P. Nerkar and R.K. Bhadekar. 2010.Isolation and characterization of salt-tolerant nitrogen-fixing microorganisms from food. J. Eur. Asia. Bio. Sci. 4: 33-40.

Nandini, K., U. Preethi, N. Earaana. 2014. Molecular identification of phosphate solubilizing bacterium (Alcaligenesfaecalis) and its interaction effect with Bradyrhizobiumjaponicum on growth and yield of soybean (Glycine max L.) African Journal of Biotechnology. 13 pp: 3450-3454

Kaya, C., H.Kirnak and D. Higgs. 2001. Enhancement of growth and normal growth parameters by foliar application of potassium and phosphorus in tomato cultivars grown at high $(\mathrm{NaCl})$ salinity. Journal of Plant Nutrition, 24: 357-367.

Khan, M.Z., S.Muhammad, M.A.Naeem, E.Akhtar and M. Khalid. 2006.Response of some wheat (Triticumae stivum L.) Varieties to foliar application of $\mathrm{N} \& \mathrm{~K}$ under rainfed conditions. Pak. J. of Bot. 38(4): 1027-1034. 
Klonowska, A., C.Gaudin, A.Fournel, M. Asso, J. le Petit, M.Giorgi and T.Tron. 2002.Characterization of a low redox potential laccase from the basidiomycete C30.European Journal of Biochemistry. 269: 6119-6125.

Kochian, L.V. 2000.Molecular physiology of mineral nutrient acquisition, transport and utilization. In: Biochemistry and Molecular Biology of Plants. B.B. Buchan, W. Gruissen, R.L. Jones (Eds.) American Society of Plant Physiology, Rockville. EUA. pp. 1204-1249.

Koroljova, O.V., E.V. Stepanova, V.P. Gavrilova, O.V. Morozova, N.V. Lubimova, A.N. Dzchafarova, A.I. Jaropolov and A. Makower.1998.Purification and characterization of the constitutive form of laccase from the basidiomycete Coriolushirsutus and effect of inducers on laccase synthesis. Biotechnology and Applied Biochemistry. 28: 47-54.

Kramer, P.J. and J.S. Boyer. 1980.Water Relations of plants and soils. Acad. Press. USA.

Kumari, A., K.K. Kapoor, B.S. Kundu, and R.K. Mehta. 2008. Identification of organic acids produced during rice straw decomposition and their role in rock phosphate solubilization. Plant Soil Environ. 54: 72.

Marschner, H. 1995. Mineral nutrition of higher plants, 2nd Ed., Academic Press, London.

Mekki, B.B., M.A. El-Kholy and E.M. Mohamed. 1999. Yield, oil and fatty acids content as affected by water deficit and potassium fertilization in two sunflower cultivars. Egypt. J. Agron. 21: 67-85.

Nautiyal, C.S., S.Bhadauria, P.Kumar, H.Lal, R.Mondal and D. Verma. 2000. Stress induced phosphate solubilization in bacteria isolated from alkaline soil. FEMS Microbiology Letters. 182:291-296.

Oosterhuis, D.M. 1998. Foliar fertilization of cotton with potassium in the USA. Proc. Symp. "Foliar Fertilization: A Technique to Improve Production and Decrease Pollution". 10-14 Eds.

Page, A.L., R.H. Miller and D.R Keeney. 1982.Methods of Soil Analysis, Part 2, Chemical and Microbiological Properties, 2nd ed., Agronomy Series No 9, American Society of Agronomy, Madison, WI.

Quesni, F.E.M., M. Z. Sahar and S.S. Hanan. 2010. Effect of microbien and compost on growth and chemical composition of Schefflere arboricola L. under salt stress. Journal of American Science. 6(10): 1073-1080.

Rahmatullah, M.A. Gill, B.Z. Shaikh and M. Salim. 1994. Bioavailability and distribution of $\mathrm{P}$ among inorganic fractions in calcareous soils.Arid Soil Res. Rehab. 8: $227-$ 234

Sabannavar, S.J. and H.C.Lakshman. 2009. Effect of rock phosphate solubilization using mycorrhizal fungi and phosphobacteria on two high yielding varieties of Sesamumindicum L. World J. Agric. Sci. 5 (4): 470-479.

Samasegaran, P., H. Hoben and J. Halliday. 1982.The NIFTAL (Nitrogen Fixation in Tropical Agricultural Legumes) Manual for methods in Legume-Rhizobium Technology.US Agency for International Development,
College of Tropical Agriculture and Resources, University of Hawai.

Samasegaran, P.H., Hoben and J. Halliday. 1982.The NIFTAL (Nitrogen Fixation in Tropical Agricultural Legumes) Manual for methods in Legume-Rhizobium Technology. US Agency for International Development, College of Tropical Agriculture and Resources, University of Hawai

Shehu, H.E., J.D. Kwari and M.K. Sandabe. 2010. Effects of N., P. and K. fertilizers on yield, content and uptake of N, $\mathrm{P}$ and $\mathrm{K}$ by sesame (Sesamum indicum L.). Int. J. Agric.Biol. 12 (6): 845-850.

Snedecor, G.W. and W.G. Cochran. 1990. Statistical Methods 8th Ed. Iowa State Univ. Press, Ames, Iowa, U.S.A.

Somida, E.G. 2002. Effect of organic manure nitrogen and potassium fertilization on growth flowering and chemical constituentsmangold plants (Tagetes minute L). M.Sc. Thesis, Fac. of Agric., Cairo Univ. pp:158.

Sonneveld, C. and C. de Kreij. 1999.Response of cucumber (Cucumis sativus L.) to an unequal distribution of salt in the root environment. Plant and Soil. 209: 47-56.

Sri, W. 2015. The effect of salinity to activity and effectivity phosphate solubilizing bacteria on growth and production of paddy . Life Sciences.2: 609-612.

Subbarao, N.S.S. 1982. Phosphate solubilizing microorganisms In: Biofertilizers in Agriculture.2nd edition. Oxford and IBH publishing Co. New Delhi, Bombay, Calcutta,India. pp: 126-132.

Subramaniam, G., V. Srinivas, B.Prakash, A.Sathya, and R.Vijayabharathi. 2015.Plant growth-promoting traits of Pseudomonas geniculata isolated from chickpea nodules Biotech. 5(5): 653-661.

Tabatabai, M.A. and J.M. Bremner 1969.Use of P-nitrophenol phosphate for assay of soil phosphatase activity. Soil Biol. Biochem. 1: 301-307.

Waller, R.A. and B.D. Duncan. 1969.A way for the symmetric multiple comparison Problem. Amer. Stat. Assoc. J. 3: 1485-1503.

Watanabe, F.S. and N. Olsen 1965. Test of an ascorbic acid method for determining phosphorus in soil, water and $\mathrm{NaHCO}_{3}$ extracts from soil. Soil Sci. Soc. Amer. Proc. 29: 677-678.

Were, B.A., A.O. Onkware, S. Gudu, M. Welander and A.S.Carlsson. 2006. Seed oil content and fatty acid composition in East African sesame (Sesamum indicum L.) accessions evaluated over 3 years. Field Crops Research. 97: 254-260.

Yeo, A.R. and T.J.Flowers. 1986. Salinity resistance in rice (Oryza sativa L.) and a pyramiding approach to breeding varieties for saline soils. Aust J Plant Physiol. 13: 161- 73.

Yermanos, D., M.J.Hemstreet, W.Saleed, C.K.Huszar. 1972. Oil content and composition of seeds in the world collection of sesame introduction. J. Agric. Chem. Soc. 49(1): 20-23.

Zhao, X. R. and Q. M.Lin. 2001. A review of phosphatedissolving microorganisms, Soil Fertilizer. 3:7-11. 


\section{الملغص العربي}

\section{تأثير البكتيريا المذيبة للفوسفات على السلوك الفسيولوجى لبعض اصناف السمسم تحت ظروف الملوحة بسهل الطينة- شمال سيناء

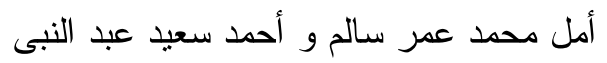

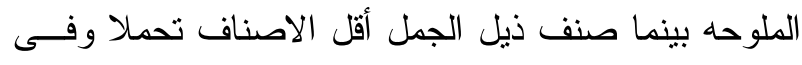

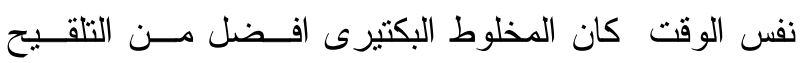

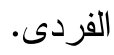

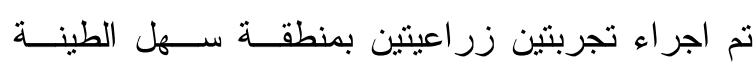

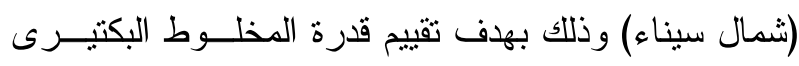

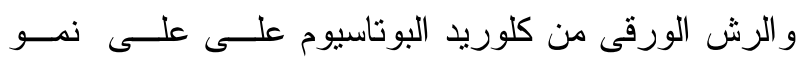

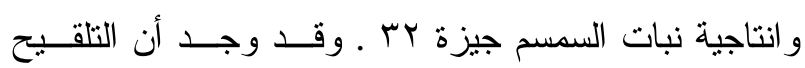

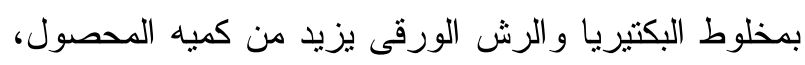

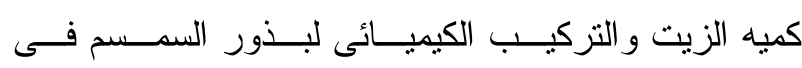

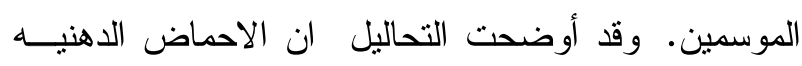

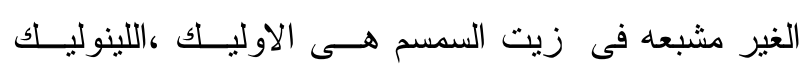

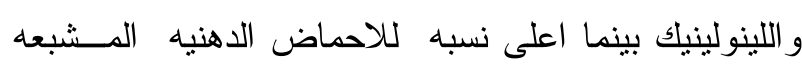

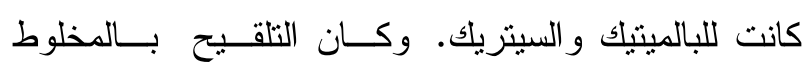

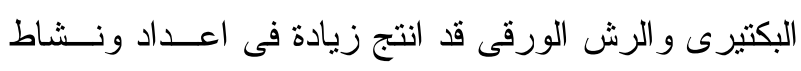
انزيم الفوسفاتيز فى منطقة الريزوسفير.
تم دراسه نشاط اربعه من السلالات البكتيريه المتحمــــهـ اللملوحه و الدذيبه للفوسفات تحت الظروف الملحيه. وقد كان

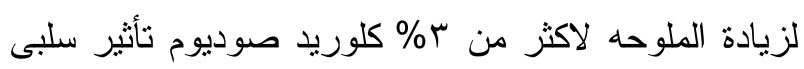

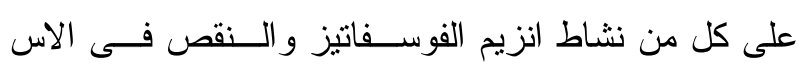

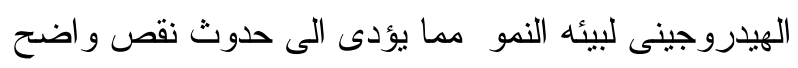

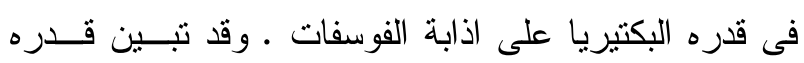

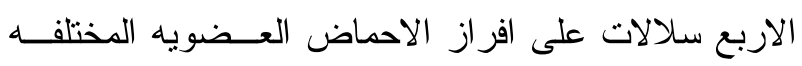

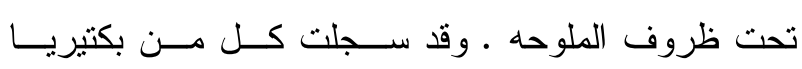
Alcaligenes faecalis و Psendomonas geniculate اذابه للفوسفات عند تركيز بّ\% كلوريد صوديوم.

تم تطبيق تجربة الاصص بالصوبة وذلك لنقيـيم

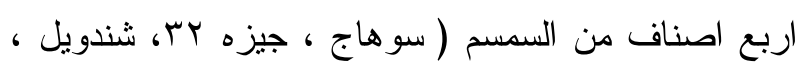
ذيل الجمل ) بجانب تثييم السلالات البكتيريه Alcaligenes faecalis g geniculate بكتيرى تحت ظروف الملوحة ـ وقد أظهــرت النتـائج أن

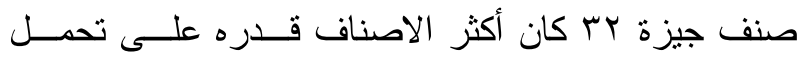

